\title{
Chronic arthritis associated with the presence of intrasynovial rubella virus
}

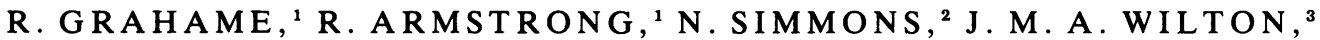 \\ M. DYSON,${ }^{4}$ R. LAURENT, ${ }^{5}$ R. MILLIS, ${ }^{6}$ AND C. A. MIMS ${ }^{7}$
}

From the Departments of ${ }^{1}$ Rheumatology, ${ }^{2}$ Clinical Microbiology, ${ }^{3}$ Oral Immunology, ${ }^{4}$ Anatomy, ${ }^{5}$ Medicine, ${ }^{6}$ Clinical Microscopy, and ${ }^{7}$ Microbiology, Guy's Hospital and Medical School, London SE1 9RT

SUMMARY In this report we present 21 instances in which live rubella virus was isolated from synovial fluid obtained from 6 cases of inflammatory oligoarthritis or polyarthritis over a period of 2 years in the absence of firm clinical evidence of rubella. In 3 cases (cases 1,2,6,) a persistent oligoarthritis predominantly affecting the knee joints occurred in 2 adult women and one man, lasting to date 27,29 , and 18 months respectively, and in one of these cases virions were found in cells of the synovial membrane. In case 3 a boy of 9 presented with an illness indistinguishable from the systemic variety of juvenile chronic arthritis (Still's disease). In case 4 a young man with persistent monoarthritis was found to have ankylosing spondylitis, and in case 5 a progressive erosive polyarthritis developed 5 years after an attack of rubella complicated by rubella arthritis. The virus was identified by a variety of virological techniques and infection confirmed by immunofluorescence and (in one case) electron microscopy.

It is now over 60 years since the first association between arthritis and rubella was reported, ${ }^{1}$ yet it took another 30 years before the clinical picture of rubella arthritis became delineated. ${ }^{2-12}$ Rubella arthritis is described in these and subsequent studies as a benign, short-duration, symmetrical polyarthritis affecting predominently the metacarpophalangeal (MCP) and proximal interphalangeal (PIP) joints of the hand, wrists, knees, and ankles. The onset of the arthritis usually coincides with the exanthem or occurs shortly therafter. The arthritis may persist for one day to several weeks, although the arthralgia may continue for several months. Over $90 \%$ of cases of rubella arthritis are seen in adult females.

Rubella virus (RV) has been isolated from the synovial fluid in naturally occurring rubella arthritis on only one occasion. ${ }^{13}$ This was a case of a 14month-old infant with rubella from whose throat and synovial fluid the virus was isolated. After the introduction of rubella immunisation with live attenuated virus in the early 1960 s arthritis was a commonly reported complication,,$^{14}$ occurring particularly in adult females. ${ }^{15}$ Live RV has been recovered from the synovial fluid from such cases ${ }^{16}{ }^{17}$ as long as 4 months after vaccination, leading to speculation that

Accepted for publication 22 December 1981. Correspondence to Dr R. Grahame. the persistent or recurrent synovitis may be the result of replication of the virus within the joint.

In this paper we report detailed investigations on 6 patients aged between 9 and 58 years suffering from a variety of chronic seronegative (IgM rheumatoid factor negative) arthritis in whom RV has been isolated from synovial fluid on one or more occasions. A preliminary report on the virus isolation methodology in relation to 5 of these patients has been published elsewhere..$^{18} \mathrm{~A}$ more detailed clinical report of case 3 has also been published previously. ${ }^{19}$

\section{Case histories}

CASE 1 (Fig. 1)

A 20-year-old female catering assistant developed a sore throat and fever in August 1979 with pain and swelling in both her knees and the right wrist. Examination revealed bilateral tense effusions of the knees and synovitis of the right wrist. She was otherwise well and afebrile, without rash or lymphadenopathy. Methyl prednisolone, $40 \mathrm{mg}$, was injected into each knee after the receipt of negative routine bacteriological cultures of synovial fluid, and the initial response was excellent. The synovitis of the knees and right wrist recurred 3 weeks later and has persisted up to the present time, that is, 2 years from the onset, increasing in severity over this period and unabated 


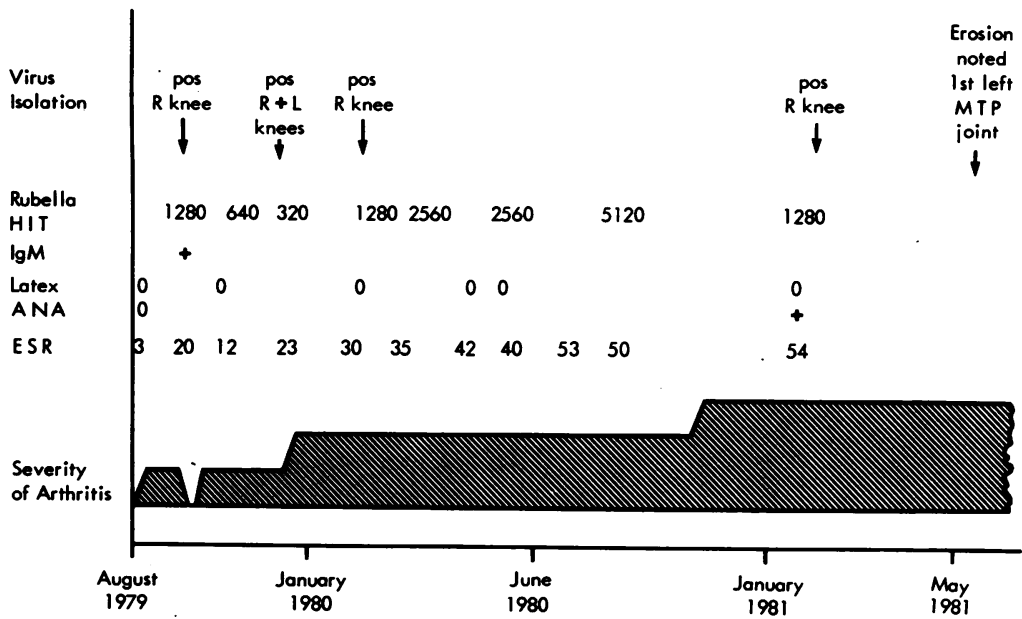

Fig. 1 Diagrammatic representation of clinical course of patient 1. by the administration of a variety of nonsteroidal anti-inflammatory drugs (NSAID) and other measures-splints, short periods of bed rest. Further intra-articular steroid injections were, however, withheld after the first positive virus isolation for fear of exacerbating the virus infection. Investigations included $\mathrm{Hb} 13.3 \mathrm{~g} / \mathrm{dl}$; leucocytes $7.8 \times 10^{9} / 1$; normal differential count; erythrocyte sedimentation rate (ESR) $3 \mathrm{~mm} / \mathrm{h}$ (rising progressively to $54 \mathrm{~mm} / \mathrm{h}$ by February 1981). Latex and sheep cell agglutinations test for rheumatoid factor, antinuclear factor (ANF), serological test for syphilis (STS), immunoglobulins, and Widal agglutinations were all negative initially, although the ANF became positive in February 1981. Standard bacteriological cultures of synovial fluid from both knees, urine, urethral swabs, throat swab, high vaginal swab, and blood were negative. Tissue typing showed HLA A1, B17, BW35, DR1, 6. Radiographs of the hands, feet knees, wrists, and chest were normal initially, but in May 1981 an erosion of the left first metatarsophalangeal (MTP) joint was identified (Fig. 2). An electrocardiogram and echocardiogram were also normal.

Routine synovial fluid cytology revealed a total

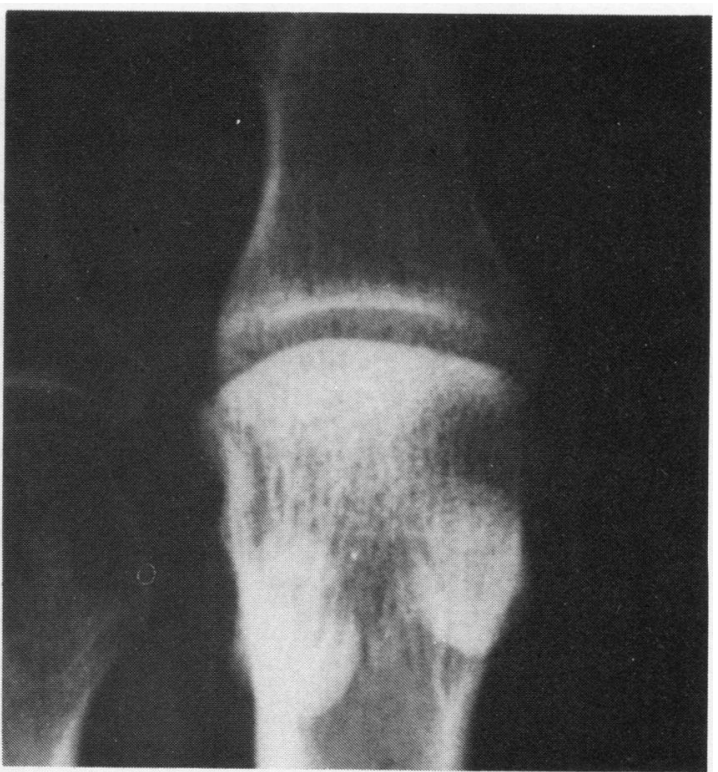

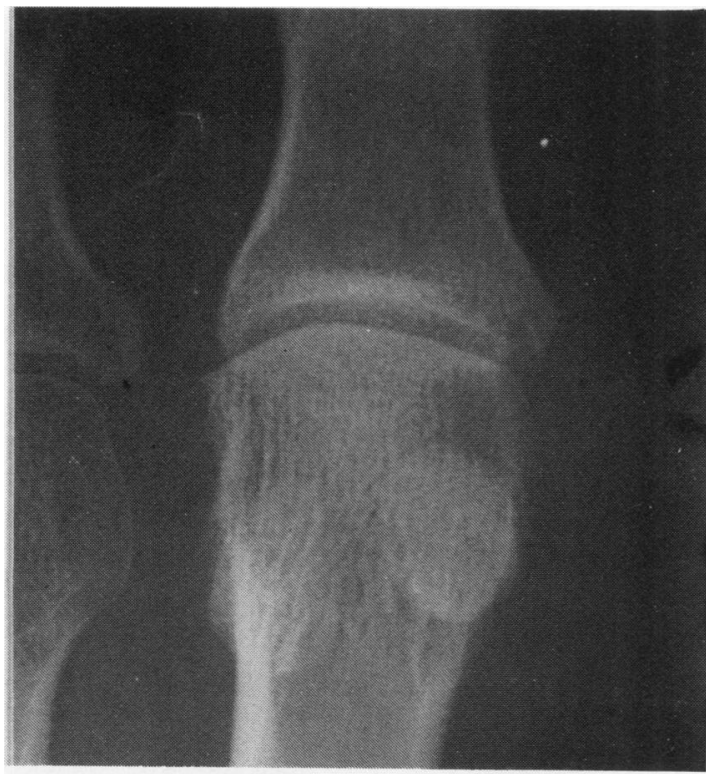

Fig. 2 Case 1. Left: Radiograph of 1st left MTP joint taken in August 1979 showing normal appearance. Right: Radiograph of same joint taken in May 1981 showing erosion of medial aspect of the base of the proximal phalanx. 


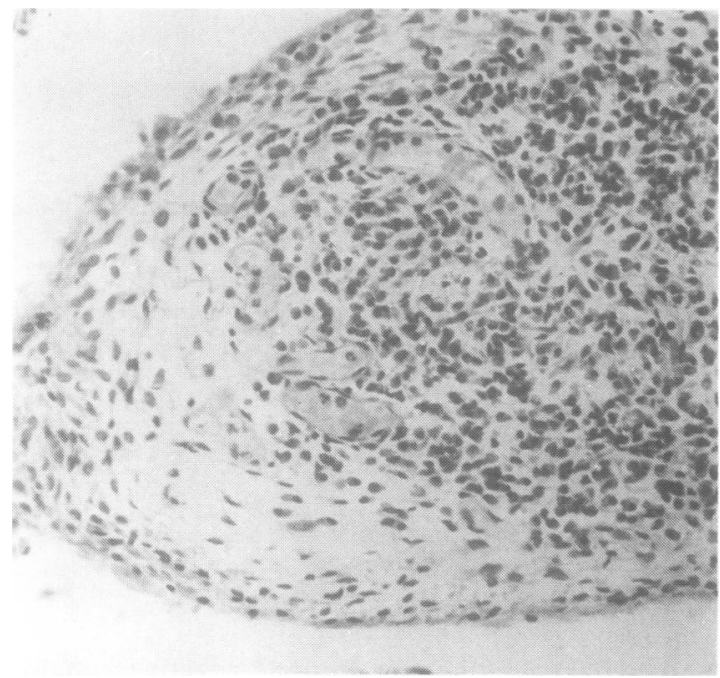

Fig. 3 Case 1. Synovial biopsy left knee, August 1979, showing hypertrophy and some hyperplasia of lining cells, hyperaemia with underlying intense perivascular cellular infiltrate consisting largely of plasma cells. $(H$ and $E, \times 24)$.

count of 12.5 cells $\times 10^{9} / 1$ in the left knee and $7 \cdot 5$, $5 \cdot 4$, and $5 \cdot 5 \times 10^{9} / 1$ (on 3 consecutive occasions) in the right knee. The predominant cell type was mononuclear. The complement level (C3) was reduced in the synovial fluid (36\%), while the C3 level in the blood was normal $(96 \%)$. Synovial biopsy showed chronic inflammatory changes (Fig. 3, Table 1). The serum rubella haemagglutination inhibition titre (HIT) in September, 1979 was 1280, and rubella specific IgM was found to be present at that time. The rubella HIT rose to a peak titre of 5120 in September 1980, subsequently falling to 1280 in February 1981. In our laboratory sera containing $7 \cdot 5 \mathrm{I} U$ of antibody per ml give an HIT of 8 . Rubella complement fixation test (CFT) titres were 64 in September and October 1979, rising to 128 in December and February 1980. $\mathrm{RV}$ was isolated from a specimen of synovial fluid from the right knee in September 1979 and subsequently in specimens obtained from both knees in December 1979, from the right knee in February 1980 and in February 1981, and again from both knees in September 1981, Further immunological and electron microscopical studies are detailed below.

\section{CASE 2(Fig. 4)}

A 40-year-old female research assistant presented with a synovitis of the right knee in May 1979. The joint was hot, painful and swollen and the patient was unable to walk. Shortly afterwards, the left knee and the PIP joints became involved. Investigations revealed $\mathrm{Hb} 13 \mathrm{~g} / \mathrm{dl}$; ESR $28 \mathrm{~mm} / \mathrm{h}$; negative latex fixation test for rheumatiod factor; tissue type HLA A1, 9, B8, DR2, 3; normal $x$-rays of her knees and hands, and negative synovial fluid culture from the left knee. The synovitis settled in 3 days. In August her symptoms recurred, with synovitis in both knees, the right knee being hot and swollen. At this time she developed a transient erythematous rash which her sister (a doctor) thought was possibly rubella. In October she was afebrile and there was no rash or lymphadenopathy, but the polyarthritis in her knees, wrists, MCP and MPT joints persisted. The ESR was $32 \mathrm{~mm} / \mathrm{h}$; the latex test was negative, but the ANF was weakly positive. Synovial fluid from the right knee showed a total of 1.9 cells $\times 10^{9} / 1$ (polymorphs $0 \cdot 3$, lymphocytes $1.6 \times 10^{9} /$. Synovial biopsy on 4 September revealed a mild synovitis with lymphocytic infiltration (Table 1). The serum rubella HIT was 80 and has subsequently varied between 20 and 80. Rubella CFT titres were 8 on all 4 occasions tested. RV was isolated from the synovial fluid obtained from the right knee on 2 occasions in October 1979, but not from a specimen taken from the same joint in January 1980 . The synovitis of her right knee persisted until January 1981. For the next 4 months she had arthralgia only, but in June the synovitis in the right knee flared, with an effusion which has persisted.

Table 1 Summary of histological findings from closed needle biopsies

\begin{tabular}{|c|c|c|c|c|c|c|}
\hline Case & $\begin{array}{l}\text { Hypertrophy of } \\
\text { lining cells }\end{array}$ & $\begin{array}{l}\text { Hyperplasia of } \\
\text { lining cells }\end{array}$ & $\begin{array}{l}\text { Perivascular lymphocyte and } \\
\text { plasma cell infiltrate }\end{array}$ & Hyperaemia & Oedema & Fibroblasts \\
\hline 1 & ++ & + & $\begin{array}{l}++ \\
\text { Plasma cells predominate }\end{array}$ & + & + & - \\
\hline 2 & ++ & ++ & $\begin{array}{l}+ \\
\text { Equal proportion of lymphocytes and } \\
\text { plasma cells }\end{array}$ & + & + & - \\
\hline 3 & - & - & - & - & - & - \\
\hline 4 & 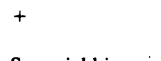 & - & $\stackrel{+}{\text { Plasma cells predominate }}$ & ++ & - & + \\
\hline $\begin{array}{l}5 \\
6\end{array}$ & $\begin{array}{l}\text { Synovial biopsy } \\
++\end{array}$ & $\begin{array}{l}\text { erformed } \\
+\end{array}$ & $\begin{array}{l}+++ \\
\text { Plasma cells predominate }\end{array}$ & ++ & - & - \\
\hline
\end{tabular}




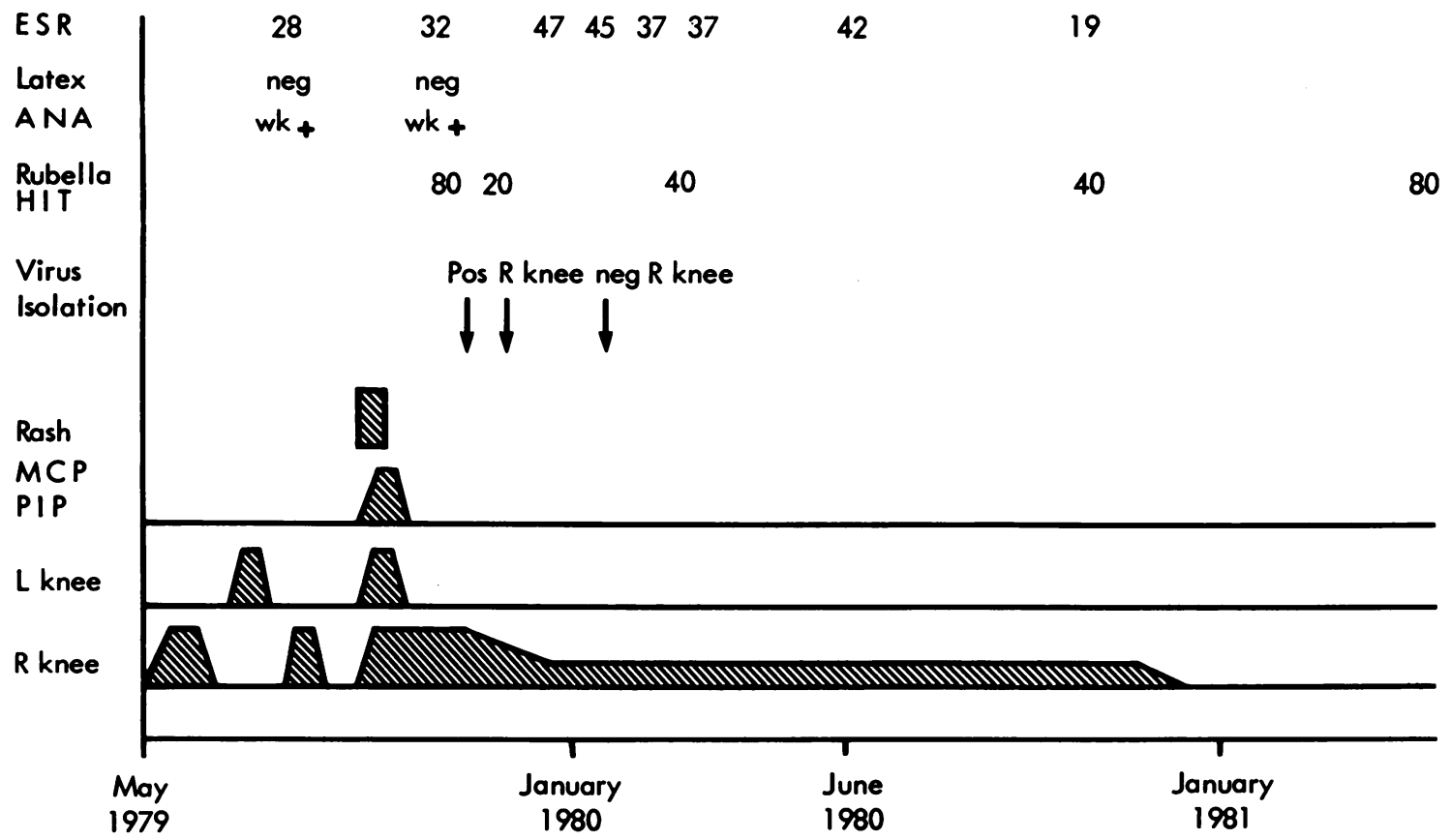

Fig. 4 Diagrammatic representation of clinical course of case 2.

CASE 3 (Fig. 5)

A 9-year-old schoolboy developed a persistent febrile illness with fever up to $40^{\circ} \mathrm{C}$ in September 1979, with an erythematous rash on his feet, trunk and elbows. A systolic murmur was audible at the left sternal edge and there was hepatosplenomegaly. A

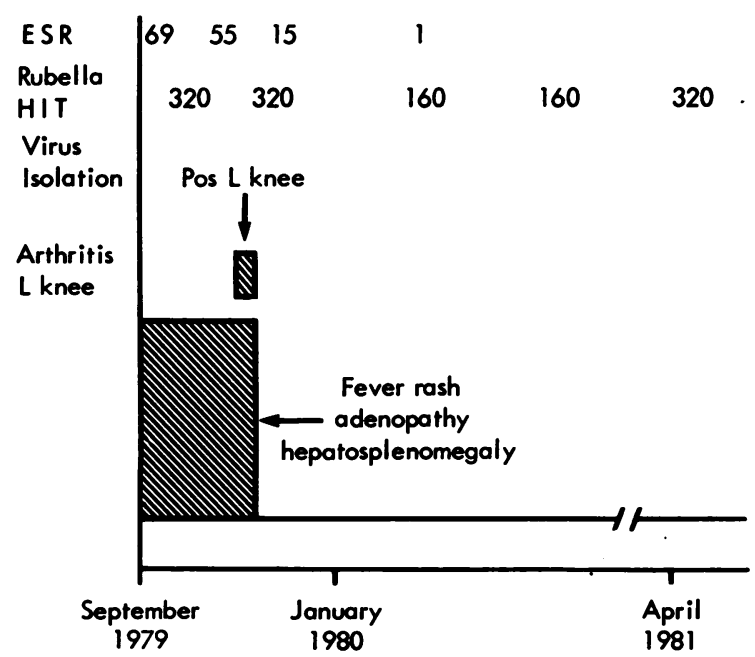

Fig. 5 Diagrammatic representation of clinical course of case 3. few lymph nodes were palpable in his neck and axillae. The rash was thought typical of Still's disease. Investigation revealed $\mathrm{Hb} 12 \mathrm{~g} / \mathrm{dl}$; leucoctyes $10 \cdot 2 \times$ $10^{9} / 1$ (polymorphs $8.2 \times 10^{9} / 1$ ), ESR $46 \mathrm{~mm} / \mathrm{h}$, immunoglobulins normal.

The serum rubella HIT was 320 , but no rubellaspecific IgM antibody was detected. Tissue typing was HLA A2, 3, B7, 12, DR4, 6. Blood cultures, throat swab, nasal swab, and urine cultures were sterile. Additional investigations included a bone marrow examination and a gallium scan, which were normal, and a liver/spleen scan, which merely confirmed the splenomegaly. It was considered at this point that Still's disease remained the most likely diagnosis despite the lack of response to salicylates, and on 30 October he was noted to have a synovitis of the left knee. A needle synovial biopsy was histologically normal (Table 1). RV was isolated from the synovial fluid obtained from the left knee. He made a good spontaneous recovery and by 14 November his ESR had fallen to $15 \mathrm{~mm} / \mathrm{h}$. The serum rubella HIT on this date was unchanged at 320 and the rubella CFT titre was 32, as it was on 7 February. When seen last in November 1981 he was in good health and had had no further symptoms of any kind. Further studies are as detailed below.

CASE 4 (Fig. 6)

A 24-year-old male bank clerk presented in June 


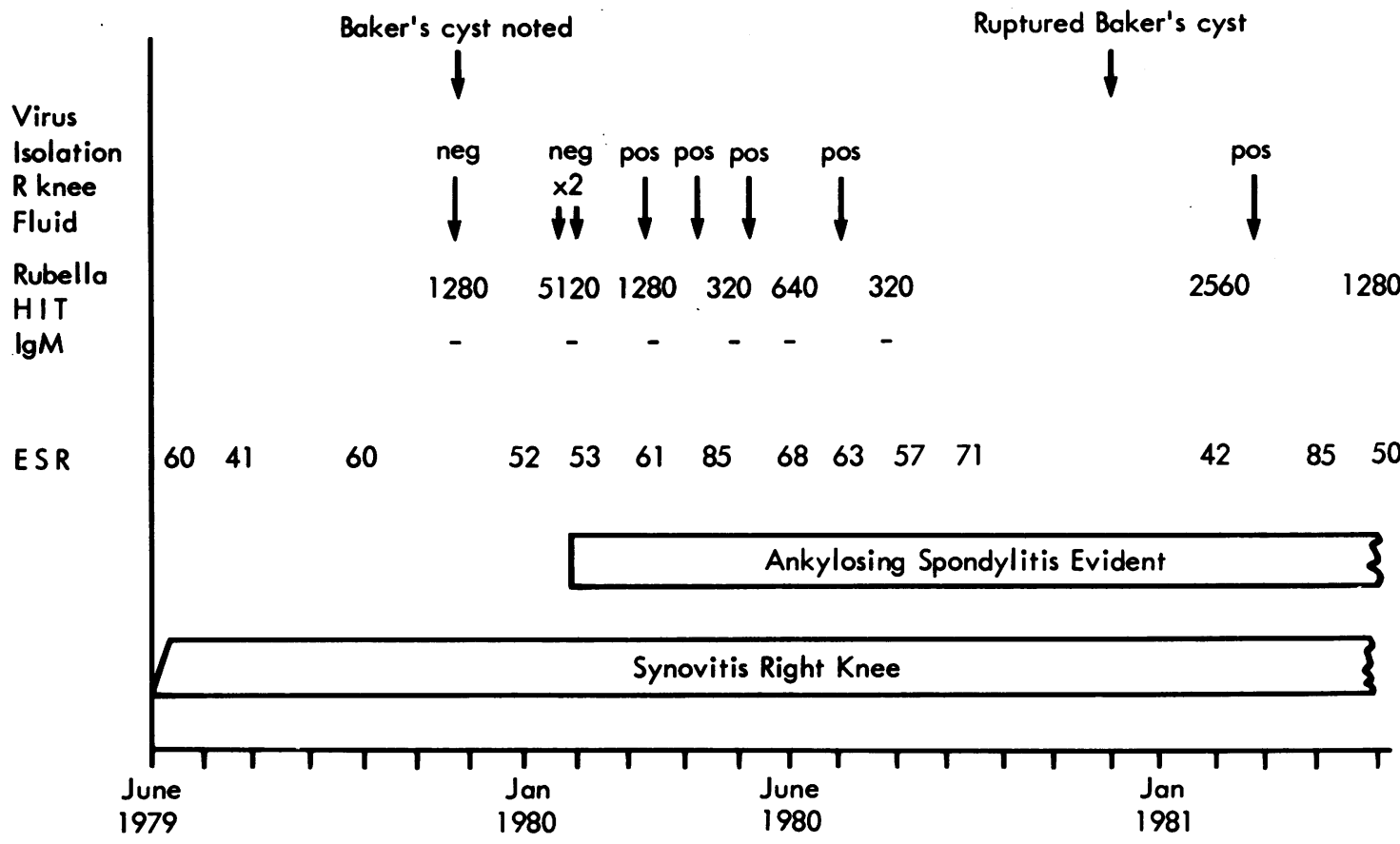

Fig. 6 Diagrammatic representation of clinical course of case 4 .

1979 with a persistent, painful, warm effusion of the right knee of sudden onset. The ESR was $60 \mathrm{~mm} / \mathrm{h}$, with a negative latex test. In December 1979 the rubella HIT was 1280 (rubella-specific IgM was not present), and the rubella CFT was 32 . Two months later he commented on back pain and stiffness and was found to be suffering from ankylosing spondylitis. His tissue type was HLA A2, B32, 27, DRI, 4. In March 1980 RV was isolated from the aspirate of his right knee ( 3 specimens tested over the previous 3 months had proved negative). Four further serial cultures of synovial fluid over the subsequent year were also positive for $R V$. The synovitis remains active up to the present time, and the rubella HIT remains elevated. The synovial biopsy findings are summarised in Table 1.

CASE 5 (Fig. 7)

A female physician contracted classical rubella (almost certainly acquired from a child patient suffering from congenital rubella) in 1974 at the age of 51. The illness was complicated by a brief episode of polyarthritis affecting her MCP and PIP joints. By 1980 she had developed a chronic, progressive symmetrical polyarthritis of her hands, wrists, shoulders and knees, with one hour of early morning stiffness, which proved to be seronegative, ANF positive, anodular, and erosive (Fig. 8), with a rubella HIT of
1280 (IgM absent) and with a positive RV isolation from the right knee aspirate.

She was treated as a case of seronegative rheumatoid arthritis with bed rest, splints, intraarticular steriod injections, and chrysotherapy. Her condition improved steadily, but despite this a second positive isolation of RV from the other (left) knee was made in 1981. A transient mild relapse occurred when chrysotherapy was interrupted in May 1981 on account of a rash. Her tissue type is HLA A2, 9, B12, 15 , DR 1,7 .

CASE 6

A 31-year-old computer programmer developed synovitis of the left ankle in May 1980 after a sporting injury, followed by synovitis in the right knee which has persisted intermittently to the present time. His investigations were as follows: $\mathrm{Hb} 15 \cdot 8 \mathrm{~g} / \mathrm{dl}$, ESR 10 $\mathrm{mm} / \mathrm{h}$, latex and ANF negative, tissue type HLA A2, 11, B5, Bw 35, C1, 4, DRI, 8. The serum rubella HIT was 40 in May and 80 in August 1981. Synovial fluid contained between 6 and $8 \times 10^{9}$ mononuclear cells $/ 1$, and on 4 consecutive occasions (May, August, September, and October, 1981) culture was positive for RV. Closed needle synovial biopsy showed a marked chronic inflammatory synovitis (Table 1). Despite an earlier episode of nonspecific 


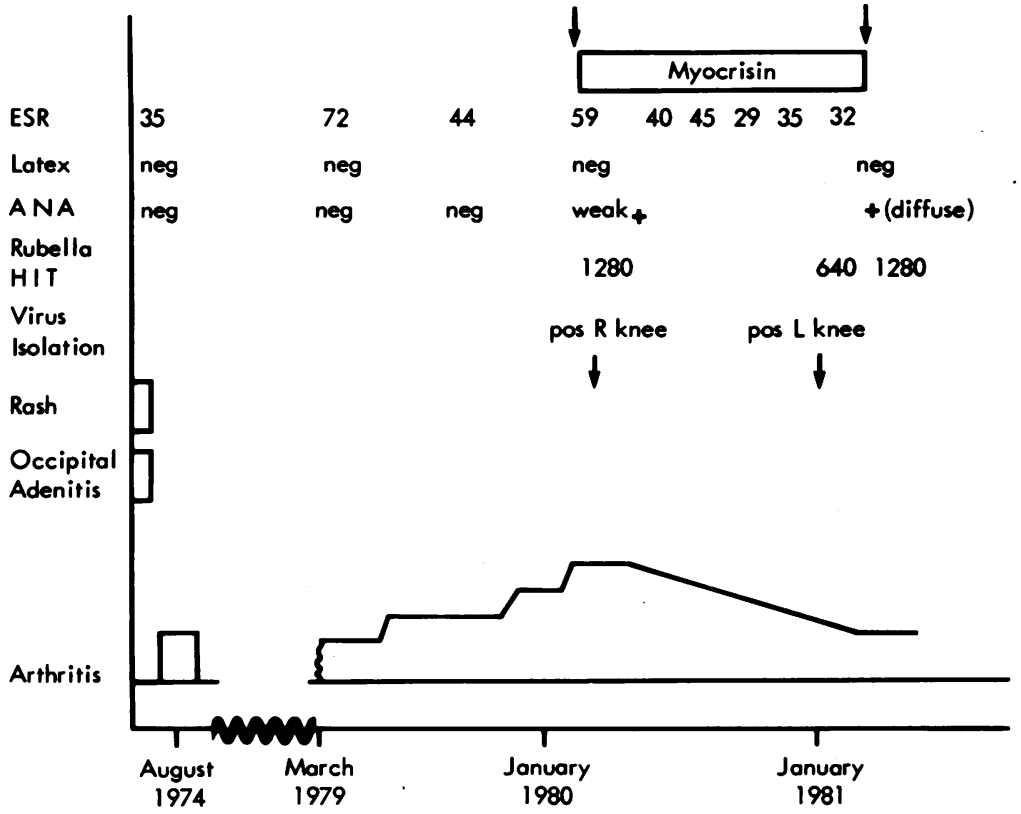

Fig. 7 Diagrammatic

representation of clinical course of case 5.

Fig. 8 Case 5. Radiograph of hands showing advanced changes or erosive arthropathy in the joints of the fingers and carpus.

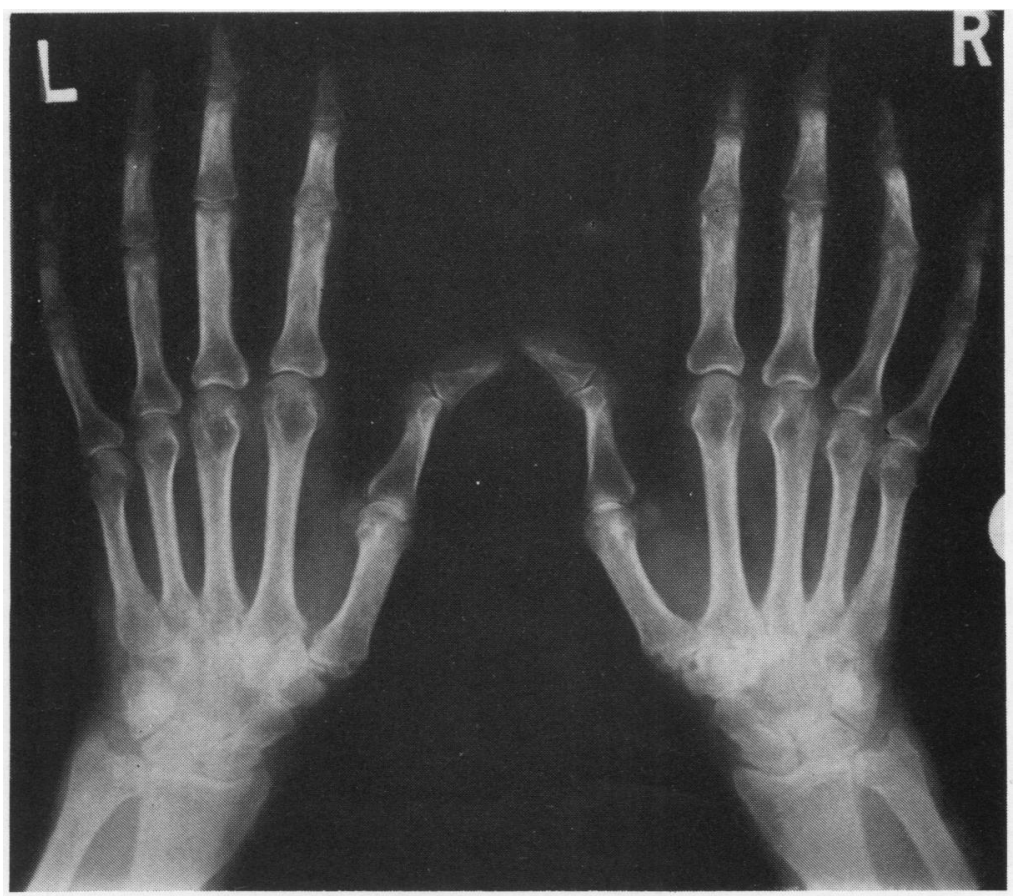




\section{Grahame, Armstrong, Simmons, Wilton, Dyson, Laurent, Millis, Mims}

urethritis a provisional diagnosis of Reiter's syndrome was changed to one of chronic rubella arthritis.

\section{Laboratory investigations}

VIRUS ISOLATION METHODS

These have been reported in detail elsewhere. ${ }^{18}$ The cells used for tissue culture were primary African green monkey kidney (AGMK), human embryonic lung (HEL), and rabbit kidney (RK13). The tissue culture medium employed was minimal essential medium (Gibco) with Earle's salts and contained $1 \%$ fetal calf serum, penicillin 100 units/ml, streptomycin $100 \mathrm{mg} / \mathrm{ml}$.

Synovial fluid $(0.2 \mathrm{ml})$ was inoculated into tissue cultures within 10 minutes of arthrocentesis. The tubes were incubated at $37^{\circ} \mathrm{C}$, and after one hour $1 \mathrm{ml}$ of the appropriate medium was added to each tube. Of each pair of tubes 1 tube of AGMK cells was incubated at $35^{\circ} \mathrm{C}$ on a roller drum and the other incubated stationary at $37^{\circ} \mathrm{C}$. The tubes were examined for cytopathic effect (CPE) daily. CPE was seen only in the AGMK cells within 7 days of incubation. CPE could not be passaged (a not uncommon feature with $\mathrm{RV}$ ), although the ECHO 11 virus interferences still occurred and rubella antigen could be identified by immunoflourescence.

Twenty-two samples of synovial fluid from patients suffering from a variety of rheumatic diseases were used as controls and subjected to identical culture procedures. They were interspersed with repeat specimens from our affected patients, and the whole series was read blind. All the controls gave negative results.

Virus identification was made by 3 antigen-specific tests: (1) detection of RV antigen incultures by complement fixation tests; (2) cell cultures inoculated with joint fluids became resistant to challenge with ECHO 11 virus (interference with ECHO 11 virus is a characteristic of cells infected with RV), and this did not occur when joint fluids were pre-treated with rubella antiserum; and (3) immunoflourescence using rabbit antirubella serum, which gave diffuse cytoplasmic staining. By these methods rubella virus was identified in 21 out of 25 synovial fluid specimens obtained from the 6 cases over the past 2 years, although not all tests were used in each case.

\section{Serological tests}

The rubella HIT and CFT were undertaken by customary test systems with standard haemagglutination and complement fixation antigens obtained from the Virus Reference Laboratory, Public Health Service, Colindale.
IgM from serum from all 6 patients was extracted on sucrose density gradients, and rubella HIT was determined. The initial sample in patient 1 was positive but on all other samples the test was negative.

\section{Antibodies to other micro-organisms}

Serum from all 6 patients was tested by complement fixation tests for antibody to the following microorganisms: Mycoplasma pneumoniae, influenza A and $\mathrm{B}$, psittacosis, respiratory syncytial virus, Coxiella burnetti, adenovirus, mumps, measles, herpes simplex, cytomegalovirus, and Epstein-Barr virus. Case 1 gave a CF titre of 40 against measles. With this exception all titres were 20 or less.

IM MUNOFLUORESCENT STUDIES

Synovial fluid cytosmears were examined in cases 1 and 2. Pericellular immunoflourescence was seen around lymphocytes and occasional neutrophils in case 1 by means of fluorescein-conjugated goat antirubella antiserum (Northeast Biomedical Laboratories $\mathrm{Ltd}$ ). In case $2,5 \%$ of the cells were large, abnormal mononuclear cells with basophilic cytoplasm. Several were multinucleate. With rubella antiserum there was marked cytoplasmic staining of these cells and also in a few neutrophils. There was no pericellular staining (Fig. 9).

Synovial biopsies from cases $1-4$ and 6 were placed in physiological saline for transport to the laboratory and snap frozen with Crysostpray (Lamb, London, UK). Sections were cut at $5 \mu \mathrm{m}$ thickness, placed on

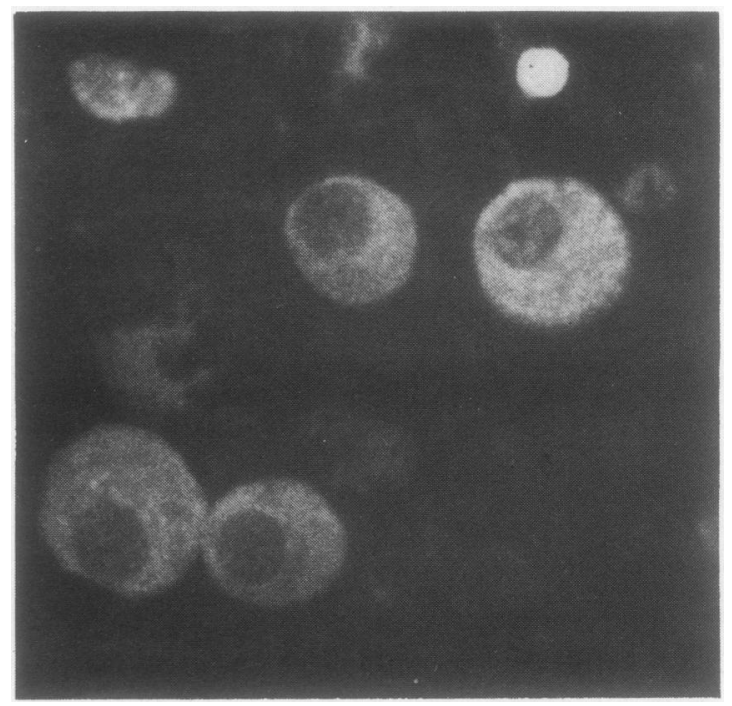

Fig. 9 Case 2. Cytosmear of synovial mononuclear cells stained with antirubella antiserum showing positive immunofluorescence in the cytoplasm. 
glass slides, and stored at $-70^{\circ} \mathrm{C}$ until used. The sections were washed in Coon's saline for 2 hours and then overlaid with deaggregated $(20000 \mathrm{~g}, 90 \mathrm{~min})$ fluorescein isothiocyanate (FITC) conjugated monospecific rabbit antihuman IgG, IgA, IgM (Wellcome Reagents, Beckenham, UK), or C3 (Hoechst, Hounslow, UK) at previously determined optimal dilutions for $30 \mathrm{~min}$ at $25^{\circ} \mathrm{C}$. For indirect testing the sections were overlaid with rabbit antirubella virus antiserum (Public Health Laboratory Service, Colindale, London) for $30 \mathrm{~min}$ at $25^{\circ} \mathrm{C}$, washed for $30 \mathrm{~min}$ at $25^{\circ} \mathrm{C}$, and then stained with FITC conjugated goat antirabbit immunoglobulin antiserum for a further $30 \mathrm{~min}$. All sections were finally washed in Coon's saline for $30 \mathrm{~min}$ and mounted in Uvinert (Gurrs, London) before being examined in Leitz Ortholux II microscope using Ploem epi-illumination and appropriate filters for FITC. No staining was observed when sections were incubated with rabbit antiherpes simplex virus type 1 or rabbit antihepatitis $B$ virus antisera. Adsorption of the rabbit antirubella antiserum with rubella complement fixation test antigen eliminated the staining when the absorption serum was used in the indirect test. Controls consisted of blocking staining with unconjugated rabbit antiimmunoglobulin or $\mathrm{C} 3$ antisera or staining with goat antirabbit FITC conjugate alone and were consistently negative. The results are summarised in Table 2.

IgG was present in sections from all 5 patients with a staining pattern that ranged from a diffuse extracellular linear staining to a more granular pattern, which was extracellular or pericellular but also occasionally intracellular. The sections from case 1 stained strongly for IgM and from case 3 stained weakly, and those from cases 2 and 4 were negative. The distribution of staining was similar to that shown for IgG. Sections from cases 1 and 3 also stained for $\operatorname{IgA}$ with less intensity than that shown for IgM or IgG, but the pattern of staining was similar to that shown for the latter immunoglobulins. Four sections showed C3 staining and a strong staining for rubella viral antigens with the extracellular staining, both linear and granular, being predominant, but there

Table $2 \operatorname{IgG}, \operatorname{IgM}, \operatorname{Ig} A, C 3$, and rubella antigen in synovial biopsies from patients with arthritis where rubella virus was isolated from synovial fluid and where there was antirubella antibody in the serum at the time of biopsy

\begin{tabular}{llllll}
\hline Case & IgG & IgM & IgA & Rubella & C3 \\
\hline 1 & ++++ & +++ & ++ & ++++ & + \\
2 & ++++ & - & - & ++++ & \pm \\
3 & +++ & + & \pm & ++ & + \\
4 & ++++ & - & - & ++++ & + \\
5 & Synovial biopsy not & performed & & \\
6 & ++++ & + & - & +++ & - \\
\hline
\end{tabular}

were again occasional granular intracellular deposits (Fig. 10).

None of the staining was present throughout the whole section but appeared to be local, some areas staining while other parts did not contain immunoglobins, C3, or rubella antigen.

\section{ELECTRON MICROSCOPY}

Synovial membrane biopsies from cases $1,2,3$, and 4 were fixed, immediately after excision, in cold glutaraldehyde fixative buffered with $0 \cdot 1$ mole phosphate at $\mathrm{pH} 7.4$ and $4^{\circ} \mathrm{C}$ for 4 hours. Each sample was then washed in phosphate buffer containing $2 \mathrm{M}$ sucrose, post-fixed in osmium tetroxide for one hour, dehydrated, and embedded in TAAB resin. Ultrathin sections were cut with an LKB Ultratome fitted with a diamond knife, stained with uranyl acetate and lead citrate, and examined with a Hitachi HU-12A transmission electron microscope.

The tissue obtained from case 1 showed the hyperaemia and infiltration with inflammatory cells noted during light microscopy. It contained densely packed aggregates of cells whose ultrastructural organisation suggested an active involvement in the synthesis of protein for export. There were few collagen fibre bundles in the intercellular spaces of these aggregates. Groups of particles $30-40 \mathrm{~nm}$ in diameter, and resembling the electron-dense cores of

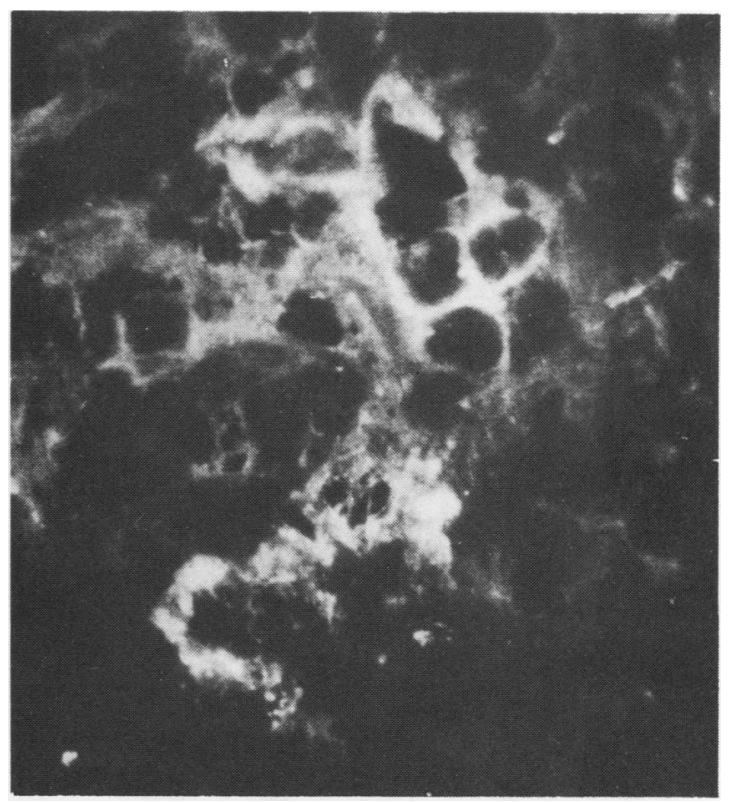

Fig. 10 Case 1. Synovial biopsy stained with goat antirubella antiserum and fluorescein-conjugated rabbit anti-goat immunoglobulin antiserum. $(\times 425)$. 


\section{Grahame, Armstrong, Simmons, Wilton, Dyson, Laurent, Millis, Mims}

rubella virus, ${ }^{20}$ were found within many of the aggregated cells (Fig. 11); they did not appear to be associated with any specific organelle and their position within the hyaloplasm was variable. Some of the particles appeared to be surrounded by a shell of less electron-dense material beyond which was a further envelope of slightly more electron-dense material, the whole resembling the apparently enveloped virions found free within the cyoplasm of cells inoculated with rubella virus. ${ }^{20}$ The possibility that such enveloped particles are secretory vacuoles cannot be entirely ruled out, although the absence of a clearly defined limiting unit membrane suggests that this is unlikely.

Intracellular particles resembling complete rubella virions lay close to the plasma membranes of some cells. Each had an electron-dense core surrounded by an envelope giving a particle with a total diameter of 50-60 nm. Cells containing rubella-like inclusions often showed severe cytopathic changes, being extensively vacuolated and containing distended and damaged mitochondria: the granular endoplasmic

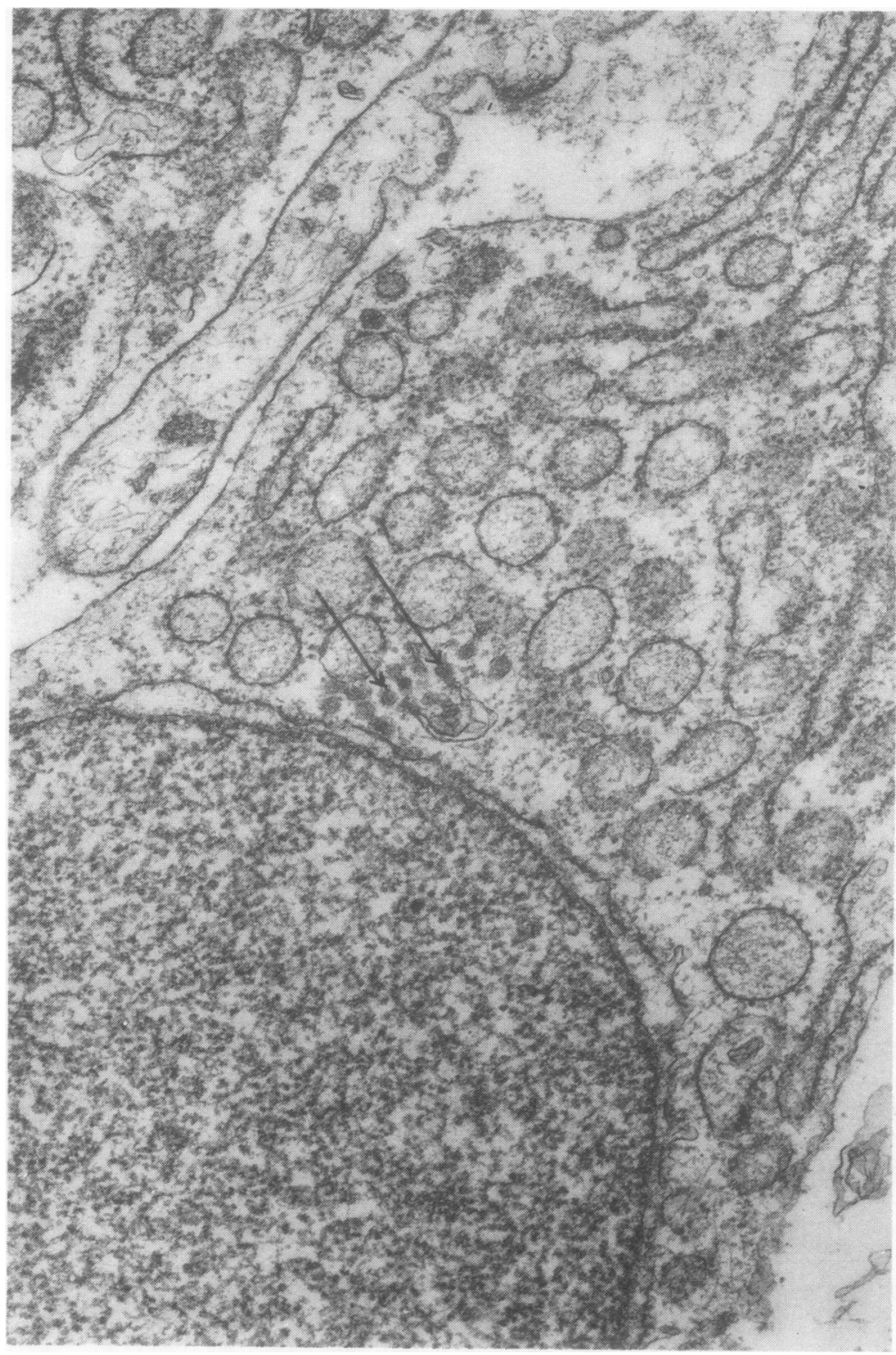

Fig. 11 Case 1. Electron micrograph of synovial biopsy. The particles (arrowed) resemble electron-dense cores of rubella virus. The copious granular endoplasmic reticulum of the cell containing them suggests an active involvement in protein synthesis. ( $\times 33700)$. 
reticulum and Golgi complexes were generally well developed. No extracellular particles of either type were identified in the samples examined.

Particles resembling rubella virus were not found in the samples obtained from cases 2,3 , or 4 , nor were there any signs of cytopathic changes.

\section{Discussion}

The unusual feature about the 6 cases of rubella arthritis reported in this paper is that in none of them was the presentation typical of rubella arthritis as reported. ${ }^{1-12}$ None displayed the characteristic clinical picture of rubella, and none would have been suspected of suffering from rubella had not specific serological and virological methods of investigation been used. Case 1 presented with a short-lived upper respiratory tract infection with fever followed by an oligoarthritis of both knees and the right wrist, which has persisted for 2 years. At no time did she have a rash or enlarged lymph nodes. While under observation she developed an erosion in the left first MTP joint. Case 2 presented with an oligoarthritis which began in the right knee, subsequently involving the left knee, wrists, and MCP and MTP joints. The condition settled in most joints, but she has a recurring synovitis of the right knee. Systemic features such as fever and lymphadenopathy were absent, but a rash (possibly a rubella rash) appeared transiently 4 months after the onset of the arthritis. Case 3 presented with the classical features of the systemic form of juvenile chronic arthritis (Still's disease) with a high fever, sore throat, hepatosplenomegaly, and a rash, considered typical of Still's disease. A transient monoarthritis of the left knee developed 7 weeks after the onset of symptoms, and it was from this joint that virus isolation was obtained. Shortly thereafter he made a complete and rapid recovery, unlike the 5 other (adult) patients.

Case 4 presented with a persistent synovitis of the right knee, from whose synovial fluid RV was ultimately and repeatedly grown. During the course of his illness and while under observation he developed ankylosing spondylitis. Case 5 presented with what appeared to be a progressive erosive seronegative arthritis 5 years after an attack of rubella arthritis. The most surprising finding was a rubella HIT of 1280 and a positive isolation of $\mathrm{RV}$ from both knees on separate occasions one year apart. Case 6 presented with an oligoarthritis of left ankle and knee after a sporting injury. Rubella HIT was only 40 , yet $\mathrm{RV}$ was isolated from the knee fluid on 4 consecutive occasions.

The immunofluorescence results and, in case 1, electron microscopy would support the concept that the synovial tissues were infected with virus. From the pattern of staining observed it would appear that the virus particles and/or viral antigens were predominantly extracellular, but in case 1 intracellular virus-like particles were also detected. The pattern of staining for IgG in all 5 patients in whom biopsies were undertaken and the presence of $\mathrm{C} 3$ in 4 and $\operatorname{IgM}$ and $\operatorname{IgA}$ in 2 , could indicate the presence of immune complexes containing the virus or viral antigens. The resistance of the immunoglobulins and $\mathrm{C} 3$ to the washing of the section would also suggest that these components were firmly bound, probably to viral antigen, in the tissues. The extracellular or pericellular distribution of the viral antigen might be due to the failure of the phagocytic cells to take up immune complexes due to the blocking of the synovial polymorphonuclear cells' FcIgG and C3b receptors by soluble immune complexes. ${ }^{21}$ The presence of low synovial fluid levels of C3 (as compared with serum levels) in these patients would also suggest immune complex formation, but the possibility that the alternative pathway was also activated cannot be ruled out. The activation of the complement sequence could thus make an important contribution to both the intensity and the chronicity of the inflammatory process. The cytoplasmic staining with antirubella antiserum of the large synovial fluid mononuclear cells in the cytosmear from case 2 is characteristic of rubella-infected cells and is similar to that previously reported by Ogra et al. ${ }^{22}$ These authors also saw extracellular staining as we did.

The diagnostic value of the serum rubella HIT was most evident in case 1 , in which a titre of 1280 was initially obtained and in which IgM antibody was detected. Case 3 showed a titre of 320 without IgM, while in cases 2 and 6 the titre was only slightly raised at 80 and 40 respectively, again without IgM. In cases 4 and 5 the highest levels were 5120 and 1280 , without IgM. Antibody titres against 12 other common viral pathogens in all cases were, by contrast, negative.

The pathognomonic feature of rubella is the typical maculopapular erythematous exanthem which appears on the face between the sixteenth and eighteenth day after the introduction of the virus into the respiratory tract. The rash spreads to the trunk and to the limbs, persisting for a period of one to 3 days before fading in the same order as it appeared. It is noteworthy that the onset of the rash coincides with the appearance of circulating antiviral antibody, suggesting that its pathogenesis may be on the basis of immune complex formation. In support of this is the observation that administration of antiviral antibody as pooled gammaglobulin to a patient soon after exposure to the virus is capable of preventing the rash but not of aborting the infection. It seems likely, therefore, that the appearance of the exanthem 


\section{Grahame, Armstrong, Simmons, Wilton, Dyson, Laurent, Millis, Mims}

depends on a critical ratio of antigen to antibody, so that if the host passes quickly from a state of viral antigen excess to one of antibody excess the exanthematous response may not occur. ${ }^{23}$ This may explain the total absence of rash in our first, fourth, and sixth patients. An alternative explanation would be that the rash in these patients passed unnoticed.

We have demonstrated that rubella infection and rubella arthritis may occur in the absence of the exanthem, and it may be that they are more prevalent than is generally recognised, particularly in times of epidemic. It is of interest in this context to note that 4 out of our 6 cases developed their symptoms between May and September 1979. There appeared to be a moderately large outbreak of rubella in England and Wales in 1979 which started earlier in the year and reached a peak in the summer months. ${ }^{24}$ Furthermore, the clinical features and natural history of rubella arthritis would appear to be more variable than is generally accepted. Five of our patients have experienced a persistent mono- or polyarthritis which at the time of writing shows no sign of abating after $27,30,29$, and 32 months respectively, while the remaining patient presented with an illness indistinguishable from Still's disease. Two of our patients have developed erosive disease, in one while under our observation. A more sinister implication of the existence of rubella infection in the absence of rash concerns the possible transmission from such unrecognised cases to women in early pregnancy.

The isolation of live rubella virus in these 5 patients suffering from inflammatory arthritis, and its intracellular location in one of these, also help to dispel the confusion that has existed as to whether arthritis in rubella is in fact due to viral involvement in synovial membrane. The fact that $\mathrm{RV}$ has been reported as having been recovered from synovial fluid on only one occasion previously in the world literature, coupled with the synchronous onset of arthritis and rash in many cases, has led to the hypothesis that the arthritis in rubella is caused by immune complex deposition as occurs in infective hapatitis and in meningococcal infection.

Attempts to implicate $\mathrm{RV}$ as the aetiological agent in juvenile or adult rheumatoid arthritis (RA) have been inconclusive. Rubella antibody appears to be no more prevalent among adult RA patients than among controls. ${ }^{25-28}$ Rubella antibody is not seen in RA synovial fluid cryoprecipitates or in eluates from rheumatoid synovial membrane..$^{29}{ }^{30}$ Other workers have shown that RA synovial fibroblasts are more resistant to infection with rubella than nonrheumatoid fibroblasts, ${ }^{31-33}$ suggesting possible intrinsic viral interference. Previously published attempts to isolate $\mathrm{RV}$ from joint aspirate in RA have failed. ${ }^{33-36}$ However, one patient with seropositive nodular disease out of a series of 10 patients with RA studied, and one patient out of 8 with indolent arthritis of the knees studied, showed consistently enhanced synovial fluid mononuclear cell responses to rubella antigen as indicated by ${ }^{3} \mathrm{H}$-thymidine incorporation. Rubella virus was subsequently isolated from these 2 patients' synovial fluid. ${ }^{37}$ Two cases are on record ${ }^{38}{ }^{39}$ in which rubella in young women was followed by a seropositive, anodular, nonerosive rheumatoid-like polyarthritis which persisted for 5 years and 20 months respectively. None of our patients has become seropositive, but 2 have erosions. Interestingly enough, 3 patients have become antinuclear-factor positive (one weakly so and 2 strongly).

Evidence for a possible association between rubella infection and juvenile chronic arthritis is perhaps more convincing. Significantly increased rubella antibody titres have been observed in a series of 42 patients with juvenile chronic arthritis, in a third of whom rubella virus antigen was detected by immunofluorescence in smears of synovial fluid. ${ }^{22} \mathrm{~A}$ subsequent study has failed to confirm this association. ${ }^{40}$ In this context our case 3 lends limited support to the possible aetiological role of rubella virus in this disease.

The most controversial matter raised by the observations reported here is the question of the precise role of RV in the pathogenesis of arthritis in these 6 patients. Although we think it unlikely, we cannot at present exclude the possibility that the RV is acting as a latent virus reactivated by an inflammatory action caused by some other mechanism. RV is known to exist for years in a latent form in the central nervous system as a rare cause of chronic encephalitis ${ }^{41}$ and in the eye and in other organs after congenital infection, ${ }^{42}$ and it is not unreasonable to speculate that the same may occur in the joint, since it is known to be an arthrotropic virus. The fact that IgM rubella-specific antibody was present only once in 30 tests undertaken in these 6 patients suggests that the infection was not recently acquired. If this were so, it would also explain why clusters of patients with chronic arthritis did not occur at times of rubella epidemics. Furthermore, the absence of raised titre of antibody to other viruses or of a general increase in polyclonal gammaglobulin would argue against an anamnestic response causing the raised IgG rubella antibody level seen.

On balance we favour the view that the evidence presented in this paper is compatible with the hypothesis that the primary pathogenic agent in the aetiology of chronic arthritis in these cases is RV. Further studies are in hand in an attempt to resolve this question. 
We thank M. R. Nevill, J. K. Walton, J. W. Cleak, C. K. Kurien, M. Crosder, D. Lovell, C. Barnes, and J. Larkin for skilled technical assistance, and Dr K. I. Welch for carrying out the tissue typing. Dr Laurent was in receipt of a Fellowship from the Special Trustees of Guy's Hospital.

\section{References}

1 Geiger J C. Epidemic of German Measles in city adjacent to army cantonment: and its probable relation thereto. JAMA 1918; 70: 1818-20.

2 Bennett R A, Copeman W S C. Notes on rubella, with special reference to certain rheumatic sequelae. $B r$ Med $J$ 1940; i: 924-6.

3 Loudon I S C. Polyarthritis in rubella. $\mathrm{Br}$ Med J 1953; i: 1388.

4 Lewis G W. Polyarthritis in rubella. Br Med J 1953; ii: 149-50.

5 Lee P R, Barnett A F, Scholer J F, Bryner S, Clarke W H. Rubella in arthritis: a study of twenty cases. Californ Med 1960; 93: 125-8.

6 Branch K G, Taylor J H. Rubella in 1962. Br Med J 1962; ii: 1325

7 Davison R H. Oedema and rubella. Br Med J 1962; ii: 414.

8 Johnston I N L. Complications of rubella. $\mathrm{Br}$ Med J 1962; ii: 414.

9 Moylan-Jones R J, Penny P T. Complications of rubella. Lancet 1962; ii: 355.

10 Lee P R. Arthritis and rubella. Br Med J 1962; ii: 925.

11 Heathfield K W G. Carpal tunnel syndrome. Br Med J 1962; ii: 58 .

12 Chambers R J, Bywaters E G. Rubella synovitis. Ann Rheum Dis 1963; 22: 263-8.

13 Hildebrandt $\mathrm{H} \mathrm{M}$, Maassab H F. Rubella synovitis in a one-year-old patient. $N$. Engl. J Med 1966: 274: 1428-30.

14 Spruance S L, Smith C B. Joint complications associated with derivatives of HPV-77 rubella virus vaccine. Am J Dis Child 1971; 122: 105-11.

15 Swartz T A, Klingberg W, Goldwasser R A, et al. Clinical manifestations, according to age, among females given HPV-77 duck rubella vaccine. Am J Epidemiol 1971; 94: 246-51.

16 Ogra P L, Herd J K. Arthritis associated with induced rubella infection. J Immunol 1971; 107: 810-3.

17 Wiebel R E, Stokes J, Buynak E B, Hilleman M R. Rubella vaccination in adult females. $N$. Engl J Med 1969: 280: 682-5.

18 Grahame $R$, Armstrong R, Simmons N A, Mims C A, Wilton J M A, Laurent $R$. Isolation of rubella virus from synovial fluid in five cases of seronegative arthritis. Lancet 1981; ii: 649-51.

19 Smith F M, Haycock G B, Grahame R. Rubella and juvenile chronic arthritis. Arch Dis Child 1981; 56: 310-1.

20 Holmes I H, Wark M C, Warburton M F. Is rubella an arbovirus? II. Ultrastructural morphology and development. Virology 1969; 37: 15-25.

21 Wilton J M A, Gibson T J, Laurent $R$, Lehner $T$. Polymorphonuclear leukocyte phagocytosis in patients with rheumatoid arthritis and Behçet's syndrome. In: Fust G, Turner M W, eds. Triggering of Phagocytic Cells. Hungary: Medicina Publishing, 1980.
22 Ogra P L, Chiba Y, Orga S S, Dzierba J L, Herd J K. Rubella virus infection in juvenile rheumatoid arthritis. Lancet 1975; i: 1157-61.

23 Heggie A D, Robbins F C. Natural rubella acquired after birth: clinical features and complications. Am J Dis Child 1969; 118: 12-7.

24 Communicable Disease Surveillance Centre (PHLS) 1978-9 (unpublished).

25 Chandler R W, Robinson H, Masi A T. Serological investigation for evidence of an infective aetiology of rheumatoid arthritis. Ann Rheum Dis 1971; 30: 274-8.

26 Laitenen O, Vesikari T, Vaheri A. Virus antibody levels in RA and SLE. Acta Med Scand 1972; 192: 37-40.

27 Simsarian J P, Roth H, Hopps H E, Douglas R D, Williams M S, Meyer H M. Serologic and virologic studies in patients with rheumatoid arthritis. Arthritis Rheum 1970; 13: 348.

28 Hart H, Marmion B P. Rubella virus and rheumatoid arthritis. Ann Rheum Dis 1977; 36: 3-12.

29 Cremer N E, Hurwitz D, Quismorio F P, Lennette E H, Friou $G$ J. Antiviral antibodies in rheumatoid synovial fluid and cryo-precipitates. Clin Exp Immunol 1974; 18: 27-37.

30 Zvaifler $\mathbf{N}$ J. The immunopathology of joint inflammation in rheumatoid arthritis. Adv Immunol 1973; 16: 265-336.

31 Grayzel A I, Beck C. Rubella infection of synovial cells and the resistance of cells derived from patients with rheumatoid arthritis. J Exp Med 1970; 131: 367-73.

32 Smith C, Hamerman D. Significance of persistent differences between normal and rheumatoid synovial membrane cells in culture. Arthritis Rheum 1969; 12: 639-54.

33 Ford D K, Oh J O. Use of synovial cell cultures in the search for virus in rheumatoid arthritis. Arthritis Rheum 1965; 8: 1047-52.

34 Barnett E V, Balduzzi P, Vaughan J H, Morgan H R. A search for infectious agents in rheumatoid arthritis. Arthritis Rheum 1966; 9: 720-4.

35 Wilkes R M, Simsarian J P, Hopps H E, et al. Virological studies in rheumatoid arthritis. Arthritis Rheum 1973; 16: 446-54.

36 Middleton P J, Highton T C. Failure to show mycoplasmas and cytopathic virus in rheumatoid arthritis. Ann Rheum Dis $1975 ; 34: 369-72$.

37 Ford D K, da Roza D M, Reid G D, Chantler J K, Tingle A J. Synovial mononuclear cell responses to rubella antigen in rheumatoid arthritis and unexplained persistent knee arthritis. $J$ Rheumatol in press.

38 Martenis T W, Bland J H, Phillips C A. Rheumatoid arthritis after rubella. Arthritis Rheum 1968; 11: 683-7.

39 McCormick J N, Duthie J J R, Gerber H, Hart H, Baker S, Marmion B P. Rheumatoid polyarthritis after rubella. Ann Rheum Dis 1978; 37: 266-72.

40 Schnitzer T J, Ansell B M, Hawkins G T, Marshall W C. Significance of rubella virus in juvenile chronic polyarthritis. Ann Rheum Dis 1977; 36: 468-70.

41 Weil M L, Itabashi H, Cremer N E. Chronic progressive panencephalitis due to rubella virus simulating SSPE. $N$ Engl J Med 1975; 292: 944-97.

42 Rawls W D. Congenital rubella: the significance of virus persistence. Prog Med Virol 1968; 10: 238-85. 